\title{
Localization of the Apoptosis-inducing Activity of Lupus Anticoagulant in an Annexin V-binding Antibody Subset
}

\author{
Norihiko Nakamura, ${ }^{\star}$ Tadanobu Ban, ${ }^{\ddagger}$ Kenji Yamaji, ${ }^{\S}$ Yoshihiro Yoneda, ${ }^{\ddagger}$ and Yoshinao Wada \\ *Department of Molecular Medicine, Research Institute, Osaka Medical Center for Maternal and Child Health, Izumi, Osaka 590-02, \\ Japan; ${ }^{\ddagger}$ Department of Anatomy and Cell Biology, Osaka University Medical School, Suita, Osaka 565, Japan; and ${ }^{\S}$ Department of \\ Nursing, School of Allied Health Sciences, Osaka University, Toyonaka, Osaka 560, Japan
}

\begin{abstract}
Lupus anticoagulant (LAC) is associated with arterial and venous thrombosis, thrombocytopenia, and recurrent fetal loss. We have reported previously that plasma with LAC activity induces apoptosis in endothelial cells and binds annexin V (Nakamura, N., Y. Shidara, N. Kawaguchi, C. Azuma, N. Mitsuda, S. Onishi, K. Yamaji, and Y. Wada. 1994. Biochem. Biophys. Res. Commun. 205:1488-1493). In this study, we separated two IgG antibody fractions, one with and one without affinity for annexin $V$, from 10 patients with LAC. LAC and apoptotic activities were localized in the annexin $\mathrm{V}$-binding fraction in all 10 patients. DNA fragmentation was dose-dependent, paralleling the amount of IgG added to the human umbilical vein endothelial cell culture medium, and was inhibited by preincubation with annexin V. Removal of the antiphospholipid antibodies from patient IgG with phospholipid liposomes did not abolish the apoptosis-inducing activities or binding to annexin V. These results imply that patients with LAC often have antibodies that do not bind phospholipids and are responsible for the induction of apoptosis in endothelial cells. (J. Clin. Invest. 1998. 101:1951-1959.) Key words: endothelial cell - apoptosis $\bullet$ inhibition $\cdot$ annexin $\mathrm{V} \cdot$ lupus anticoagulant
\end{abstract}

\section{Introduction}

Lupus anticoagulant (LAC) ${ }^{1}$ is an autoantibody found in patients with SLE and various other autoimmune disorders

Address correspondence to Dr. Yoshinao Wada, Department of Molecular Medicine, Research Institute, Osaka Medical Center for Maternal and Child Health, 840 Murodo-cho, Izumi, Osaka 590-02, Japan. Phone: 725-56-1220, ext. 5206; FAX: 725-57-3021; E-mail: j61638@center.osaka-u.ac.jp

Received for publication 21 February 1996 and accepted in revised form 3 March 1998.

1. Abbreviations used in this paper: AAC, apoptotic adherent cells; APTT, activated partial thromboplastin time; $\beta_{2} \mathrm{GPI}, \beta_{2}$-glycoprotein I; CL, cardiolipin; $C L / \beta_{2}$ GPI, mixture of $C L$ and $\beta_{2}$ GPI; dAPTT, dilute activated partial thromboplastin time; ESC, phospholipid mixture composed of PE, PS, and PC; HUVEC, human umbilical vein endothelial cells; $\mathrm{IgG} /+$ ANX, annexin $\mathrm{V}$-binding $\mathrm{IgG}$ antibodies; $\mathrm{IgG}$ - ANX, annexin V-nonbinding IgG antibodies; LAC, lupus anticoagulant; PC, phosphatidylcholine; PE, phosphatidylethanolamine; PS, phosphatidylserine.

J. Clin. Invest.

(C) The American Society for Clinical Investigation, Inc. 0021-9738/98/05/1951/09 \$2.00

Volume 101, Number 9, May 1998, 1951-1959

http://www.jci.org
(1-3). LAC inhibits coagulation in vitro, but is paradoxically associated with thrombosis as well as recurrent fetal loss and thrombocytopenia in affected patients (4-7). Although lines of evidence suggest that LAC binds negatively charged phospholipids or phospholipid-binding proteins, the mechanism underlying thrombophilia has not been precisely determined (6-14). Among the numerous hypotheses put forth, including impaired fibrinolytic activity (15-17), imbalance of the prostacyclin-thromboxane system (18-20), increased circulation of von Willebrand factor (15), impaired thrombomodulin activity $(21,22)$, and inhibition of activated protein C activity (23-26), several have focused on impairment of the antithrombogenic function of endothelial cells (27-32). Given this possibility, the observation of LAC-induced apoptosis in human umbilical vein endothelial cells (HUVEC) points to a cellular mechanism underlying the local defect in the integrity of vascular hemostasis (33).

In a previous report, we presented evidence for the possible involvement of annexin V in LAC-induced apoptosis (33). Annexin $\mathrm{V}$ is a $\mathrm{Ca}^{2+}$-dependent phospholipid-binding protein abundant in endothelial cells which has been suggested to play a role in preventing blood coagulation by shielding negatively charged phospholipids from intrinsic and extrinsic coagulation factors and platelets (34-37). Based on the accumulating data regarding the roles of annexin $\mathrm{V}$ in cell cycle regulation, intracellular signal transduction, and membrane organization or disorganization (for reviews see references 38-40), this protein is a likely participant in apoptosis. Our previous demonstration that rabbit IgG against human annexin $\mathrm{V}$ binds phospholipids and has anticoagulant activity (41) as well as inducing apoptosis in HUVEC (33) supports the hypothesis that this protein plays a role in apoptosis.

In this study, IgG antibodies with the capacity to bind annexin $\mathrm{V}$ were isolated from patient plasma which induced apoptosis in HUVEC. The apoptosis-inducing activity was localized in the annexin $\mathrm{V}$-binding antibodies, and could be prevented by preincubation with annexin $\mathrm{V}$.

\section{Methods}

Patients. Plasma was obtained from 10 female patients, 9 with SLE and 1 with an unclassified autoimmune disease (Table I). All had LAC and a history of fetal loss. All SLE patients had satisfied the American Rheumatism Association criteria for the diagnosis (42). The plasma of these patients was capable of inducing apoptosis in HUVEC (33). Pooled plasma (Standard-Human-Plasma) was purchased from Behring (Marburg, Germany).

LAC positivity was confirmed according to the criteria below. $(A)$ Activated partial thromboplastin time (APTT) and dilute APTT (dAPTT) were both 2 SD above the mean derived from measurements in more than 2,000 women. The phospholipid source Platelin (Organon Teknika, Durham, NC) was used at a 1:20 dilution for dAPTT. Platelin is a phospholipid mixture containing phosphatidylethanolamine (PE), phosphatidylserine (PS), phosphatidylcholine 
Table I. Patient Characteristics and Anticoagulant Activities of Plasma

\begin{tabular}{lccccc}
\hline \multicolumn{1}{c}{ Patient } & Age & Diagnosis & Complication & APTT & dAPTT \\
\hline & $y r$ & & & $s$ & $s$ \\
1 & 38 & LAC alone & fetal loss $\times 2$ & 49.6 & 96.7 \\
2 & 43 & SLE & fetal loss $\times 4$ & 72.9 & 107.4 \\
3 & 32 & SLE & fetal loss $\times 5$ & 88.4 & 136.7 \\
4 & 34 & SLE & fetal loss $\times 3$ & 45.5 & 97.5 \\
5 & 31 & SLE & fetal loss $\times 2$ & 45.5 & 145.7 \\
6 & 41 & SLE & fetal loss $\times 1$ & 65.0 & 106.8 \\
7 & 43 & SLE & fetal loss $\times 8$ & 47.0 & 112.0 \\
8 & 42 & SLE & fetal loss $\times 5$ & 71.3 & 148.7 \\
& & & cerebral thrombosis & & \\
9 & 34 & SLE & fetal loss $\times 6$ & 124.6 & 240.1 \\
10 & 34 & SLE & fetal loss $\times 1$ & 71.37 & 155.63 \\
Control 1 & 24 & - & - & 36.71 & 64.45 \\
Control 2 & 30 & - & - & 35.41 & 60.91 \\
Pooled plasma & - & - & - & 36.09 & 55.24 \\
& & & & & \\
\hline
\end{tabular}

Normal ranges for APTT and dAPTT are $36.7 \pm 4.2 \mathrm{~s}($ mean $\pm \mathrm{SD})$ and $59.4 \pm 10.9 \mathrm{~s}$, respectively.

(PC), sphingomyelin, and phosphatidylinositol. (B) The prolongation of APTT and dAPTT could not be corrected by mixing with the same volume of normal plasma. $(C)$ There was no administration of anticoagulant drugs at the time of blood collection. $(D)$ Antibody against a specific coagulation factor was absent. $(E)$ There was no history of bleeding diathesis.

Isolation of annexin $V$-binding IgG antibodies. An annexin $\mathrm{V}$ affinity column was prepared by coupling $5 \mathrm{mg}$ of human annexin $\mathrm{V}$ to an $N$-hydroxysuccinimide-activated Sepharose column with a $1-\mathrm{ml}$ bed volume (HiTrap NHS; Pharmacia, Uppsala, Sweden) according to the manufacturer's directions. Annexin V from human placenta (43) was a generous gift from Kowa Co. (Tokyo, Japan). Coupling efficiency was $95 \%$. IgG was isolated with a protein G column (Pharmacia) and dialyzed against PBS. The $\mathrm{IgG}$ antibodies $(0.7-1.0 \mathrm{mg})$ were applied to an annexin $\mathrm{V}$ affinity column. The fraction passed through the column was collected. After washing with 20 -mM sodium phosphate buffer, $\mathrm{pH} 7.0$, the annexin $\mathrm{V}$-binding fraction was obtained by eluting the column with $0.1 \mathrm{M}$ glycine- $\mathrm{HCl}, \mathrm{pH} 2.7$, followed by neutralization with one-tenth volume of $1 \mathrm{M}$ Tris- $\mathrm{HCl}, \mathrm{pH}$ 9.0. The fractions were concentrated and dialyzed against PBS.

Measurement of antiphospholipid and anti-annexin $V$ activities. Antiphospholipid and anti-annexin V activities were analyzed by an ELISA as described below. Microtiter wells (ICN, Horsham, PA) were coated with $100 \mu \mathrm{l}$ of $20 \mu \mathrm{g} / \mathrm{ml}$ recombinant annexin V (36) (Kowa Co.), with $25 \mu \mathrm{l}$ of $100 \mu \mathrm{g} / \mathrm{ml}$ cardiolipin (CL), or with $125 \mu \mathrm{g} / \mathrm{ml}$ PS or Platelin in ethanol. 50- $\mu \mathrm{l}$ samples of $20 \mu \mathrm{g} / \mathrm{ml}$ unseparated or separated IgG were then incubated in wells for $30 \mathrm{~min}$ at $37^{\circ} \mathrm{C}$. The anti-CL activity was measured by incubating IgG samples with $15 \mu \mathrm{g} / \mathrm{ml}$ of $\beta_{2}$-glycoprotein I ( $\beta_{2} \mathrm{GPI}$ ) or without $\beta_{2}$ GPI. Excess proteins were washed with PBS containing $0.05 \%$ Tween 20 . Bound antibodies were detected using a 1:500 dilution of goat anti-human $\operatorname{IgG}(\gamma$-chain specific) conjugated to alkaline phosphatase (Sigma Chemical Co., St. Louis, MO) and $p$-nitrophenyl phosphate. The second antibody did not show binding activity to annexin V, $\beta_{2}$ GPI, CL, PS, Platelin, or a mixture of CL and $\beta_{2}$ GPI $\left(\mathrm{CL} / \beta_{2} \mathrm{GPI}\right)$. $\beta_{2}$ GPI was purified from the serum of a healthy individual by the method of Wurm (44), and purity was verified by SDS PAGE.

Measurement of the anticoagulant activity of $\operatorname{Ig} G$. The effect of the total or separated $\mathrm{IgG}$ on in vitro coagulation was examined by dAPTT, in which Platelin was used at a dilution of 1:20. A 50- $\mu$ l solu- tion of $\mathrm{IgG}, 7.5 \mathrm{mg} / \mathrm{ml}$ (final $1.5 \mathrm{mg} / \mathrm{ml}$ in dAPTT solution) for total IgG and $0.3 \mathrm{mg} / \mathrm{ml}$ (final $60 \mu \mathrm{g} / \mathrm{ml}$ ) for separated $\mathrm{IgG}$, in PBS was mixed with the same volume of pooled plasma (Verify 1; Organon Teknika) and incubated for $5 \mathrm{~min}$ at room temperature. Then, $50 \mu \mathrm{l}$ of 20 -fold diluted Platelin and $50 \mu \mathrm{l}$ of $0.5 \%$ kaolin in PBS were added to the mixture. After incubating for $5 \mathrm{~min}$ at $37^{\circ} \mathrm{C}, 50 \mu \mathrm{l}$ of $32-\mathrm{mM} \mathrm{CaCl}_{2}$ was added and the clotting time was recorded. The assay was done in duplicate and the mean value was adopted. The coefficient of variation was less than $3 \%$. The IgG solution was substituted with the same volume of PBS alone in a control study.

Measurement of fragmented DNA by ELISA. Primary cultures of HUVEC were purchased from Morinaga (Yokohama, Japan), and were grown in collagen-coated dishes using MCDB104 medium with $5 \%$ FBS, $5 \mu \mathrm{g} / \mathrm{ml}$ endothelial cell growth supplement, and $10 \mu \mathrm{g} / \mathrm{ml}$ heparin. The HUVEC were used at population-doubling levels of 4-11.

Growing cells $\left(10^{6}\right)$ were labeled with 10-mM 5-bromo-2'-deoxyuridine for 16-18 $\mathrm{h}$, and then detached by EDTA/trypsin treatment. The cells were collected by centrifugation at $250 \mathrm{~g}$ for $10 \mathrm{~min}$ and suspended in a fresh culture medium to make $2.5 \times 10^{4}$ cells $/ \mathrm{ml} .100 \mu \mathrm{l}$ of the cell suspension was transferred to each well of a microculture plate coated with type I collagen (Biocoat Cellware; Becton Dickinson, Bedford, MA) and grown for $14 \mathrm{~h}$. After washing with PBS, the cells were further incubated in $200 \mu \mathrm{l}$ of fresh culture medium containing test samples. At various time points during the culture period, $20 \mu \mathrm{l}$ of lysis buffer was added to the wells or to the supernatants obtained by centrifugation, and the amounts of fragmented DNA were measured with a cellular DNA fragmentation ELISA kit (Boehringer Mannheim, Mannheim, Germany) (45). For hematoxylin/eosin staining, supernatants in the wells were removed by aspiration after the indicated culture periods, and the remaining cells were then stained. All assays were performed in triplicate and the mean value was adopted.

Phospholipid liposomes. CL, PS, or a phospholipid mixture (ESC) composed of PE, PS, and PC (4:2:4) in chloroform was evaporated to dryness, resuspended in cold PBS, and sonicated. In some experiments, CL liposomes were mixed with $15 \mu \mathrm{g} / \mathrm{ml}$ of $\beta_{2}$ GPI in PBS (CL-liposome $/ \beta_{2} \mathrm{GPI}$ ).

Inhibition study. Separated IgG samples $(20 \mu \mathrm{g} / \mathrm{ml})$ were incubated with varying concentrations of phospholipid liposomes in PBS at $37^{\circ} \mathrm{C}$ for $1 \mathrm{~h}$ and then at $4^{\circ} \mathrm{C}$ overnight with stirring. Incubation with annexin $\mathrm{V}$ or $\beta_{2}$ GPI was performed at $37^{\circ} \mathrm{C}$ for $30 \mathrm{~min}$. After incubation, the residual binding activity to phospholipids or annexin $\mathrm{V}$ was measured by ELISA as described above. For ESC liposomes, each well of an ELISA plate was coated with $25 \mu \mathrm{l}$ of $100 \mu \mathrm{g} / \mathrm{ml} \mathrm{ESC}$ in ethanol. In the case of CL-liposome $/ \beta_{2} \mathrm{GPI}$, the samples were incubated with varying concentrations of CL liposomes and a final concentration of $15 \mu \mathrm{g} / \mathrm{ml} \beta_{2}$ GPI, and then the anti-CL antibodies were measured.

Total IgG samples $(1.5 \mathrm{mg} / \mathrm{ml})$ were incubated with varying concentrations of annexin $\mathrm{V}$ at $37^{\circ} \mathrm{C}$ for $30 \mathrm{~min}$. The samples were then diluted to $0.2 \mathrm{mg} / \mathrm{ml}$, and $50-\mu \mathrm{l}$ samples were subjected to ELISA.

For fragmentation ELISA, a total of $100 \mu$ of the incubated solution was used as an effector. Cell culture and the ELISA of fragmented DNA were performed as described above.

Removal of phospholipid-binding activity by liposomes. A final $5-\mathrm{mg} / \mathrm{ml} \mathrm{IgG}$ solution in PBS was mixed with varying amounts of phospholipid liposomes. The mixture was incubated at $37^{\circ} \mathrm{C}$ for $1 \mathrm{~h}$, and then at $4^{\circ} \mathrm{C}$, overnight, with stirring. After centrifugation at $100,000 \mathrm{~g}$ for $30 \mathrm{~min}$, the supernatant was extracted three times with butanol and twice with chloroform to remove free phospholipids. The resulting $\mathrm{IgG}$ solution was adjusted to $0.2 \mathrm{mg} / \mathrm{ml}$ in PBS and examined for antiphospholipid and apoptosis-inducing activities as described above.

\section{Results}

IgG from patients with LAC has both antiphospholipid and anti-annexin $V$ activities. The $\mathrm{IgG}$ antibodies isolated from 

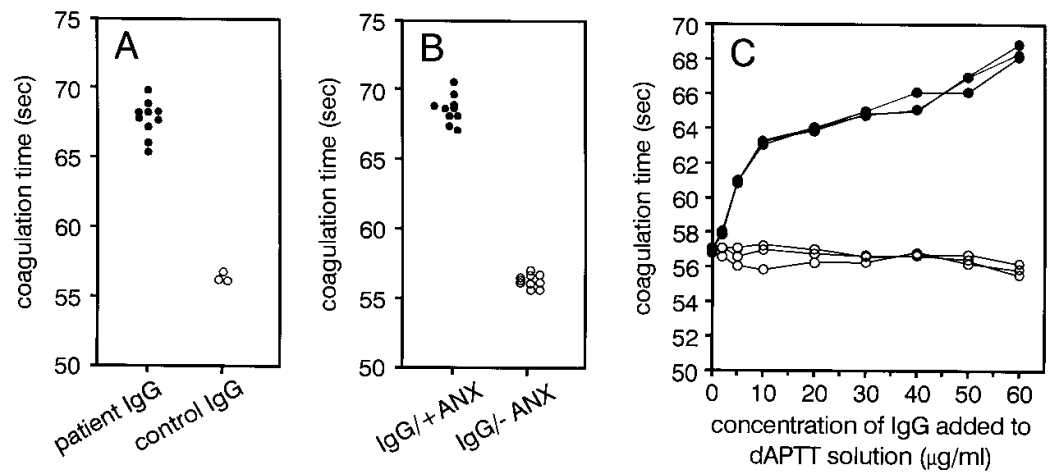

Figure 1. LAC activities of total and separated $\operatorname{IgG}$ antibodies. Inhibition of the coagulation of pooled plasma (Verify 1) by the same volume of total IgG (final $1.5 \mathrm{mg} / \mathrm{ml}$ in the dAPTT solution) or separated IgG (final $60 \mu \mathrm{g} / \mathrm{ml}$ ) was measured by dAPTT. The average time values of duplicate measurements are presented. $(A)$ Total IgG; control IgGs were obtained from two healthy individuals and the pooled plasma.

(B) Separated IgG from patients; the difference between two fractions was significant $(68.5 \pm 1.0 \mathrm{~s}$ $[$ mean \pm SD $]$ vs. $56.3 \pm 0.6 \mathrm{~s}[P<0.001])$. $(C)$ Dosedependent effect of separated IgGs from three patients. Closed circles, IgG/+ANX; open circles, $\mathrm{IgG} /-\mathrm{ANX}$. the patients with LAC exhibited LAC activity as determined by dAPTT (Fig. $1 A$ ). The binding activities to phospholipids including CL, PS, and a complex mixture of phospholipids (Platelin) were also demonstrated in these antibodies by ELISA (Fig. $2 A$ ), and the binding to CL was enhanced by $\beta_{2}$ GPI, in accordance with the notion that the binding to CL in ELISA of autoimmune antibodies, which differs from that of syphilis-induced antibodies, is dependent upon the presence of $\beta_{2}$ GPI (46-50). The patient IgG also exhibited anti-annexin V activity, consistent with our previous observations on monoclonal LAC and patient plasma $(33,51)$.

Antiphospholipid activities in the annexin $V$-binding IgG. The annexin V-binding IgG antibodies (IgG/+ANX) were isolated with an annexin $\mathrm{V}$ affinity column. The recovered $\mathrm{IgG} /+\mathrm{ANX}$ fraction accounted for $2-6 \%$ of the total $\mathrm{IgG}$ from patients, but less than $0.01 \%$ of that from the controls.
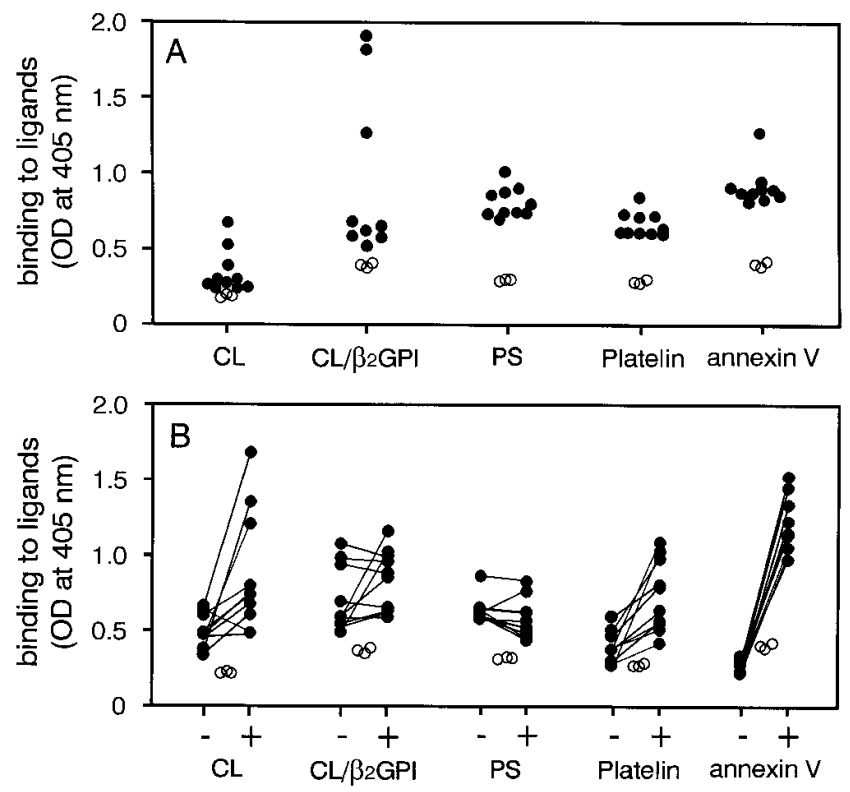

Figure 2. Antiphospholipid and anti-annexin $\mathrm{V}$ activities of total and separated $\mathrm{IgG}$ antibodies. The binding to phospholipids and annexin $\mathrm{V}$ of total $(A)$ and separated $(B)$ IgGs was analyzed by ELISA. Closed circles, patient IgGs; open circles, control IgGs from two healthy individuals and a pooled plasma sample.,$+ \mathrm{IgG} /+\mathrm{ANX}$ and ,$- \mathrm{IgG} /-\mathrm{ANX}$.
LAC activities of $\mathrm{IgG} /+\mathrm{ANX}$ and the unbound fraction (IgG/-ANX) were analyzed by dAPTT. IgG/+ANX prolonged the coagulation time by more than $15 \%$ in contrast to the IgG/-ANX fraction displaying no such LAC activity, indicating the localization of LAC in IgG/+ANX (Fig. $1 B$ ). This prolongation was dose-dependent (Fig. 1C).

Antiphospholipid antibodies in these fractions were then measured by ELISA. The IgG/+ANX fraction exhibited binding to $C L$, Platelin, and $C L / \beta_{2}$ GPI to a greater extent than $\mathrm{IgG} /-\mathrm{ANX}$ in most patients, although both contained antiphospholipid antibodies (Fig. 2 B). The anti-PS activity did not differ among these fractions. However, when their activities were compared using an inhibition assay, in which phospholipid liposomes were used as a competitor of the coated phospholipids, the apparent affinity of IgG/+ANX to PS liposomes was lower than that of IgG/-ANX (Fig. 3). Similar results were obtained for CL, CL-liposome $/ \beta_{2}$ GPI, ESC, and Platelin (data not shown), suggesting that the relative affinities to the coated and liposomal forms of phospholipids differed between $\mathrm{IgG} /+\mathrm{ANX}$ and $\mathrm{IgG} /-\mathrm{ANX}$.

Binding of $I g G /+A N X$ to annexin $V$ is partially inhibited by phospholipids. To clarify the relationship between the antiphospholipid and anti-annexin $\mathrm{V}$ activities of $\mathrm{IgG} /+\mathrm{ANX}$, ELISA of the latter activity was performed in the presence of phospholipid liposomes. As shown in Fig. 4, the binding of $\mathrm{IgG} /+\mathrm{ANX}$ to annexin $\mathrm{V}$ was inhibited in the presence of CLor PS-liposomes, but, in either case, only partial inhibition was achieved even with a large excess of these phospholipid

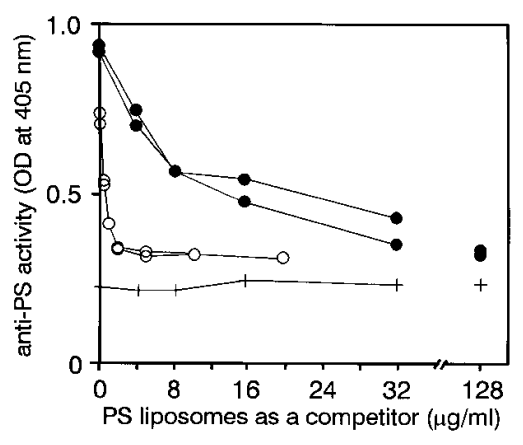

Figure 3. Inhibition of the anti-PS activity by PS liposomes. Separated $\operatorname{IgG}(20 \mu \mathrm{g} / \mathrm{ml})$ was preincubated with varying concentrations of PS liposomes, and then the antibodies bound to the PS coated on the ELISA plate were measured. Two patients were analyzed. Closed circles, $\mathrm{IgG} /+\mathrm{ANX}$; open circles, IgG/-ANX +, control IgG. 

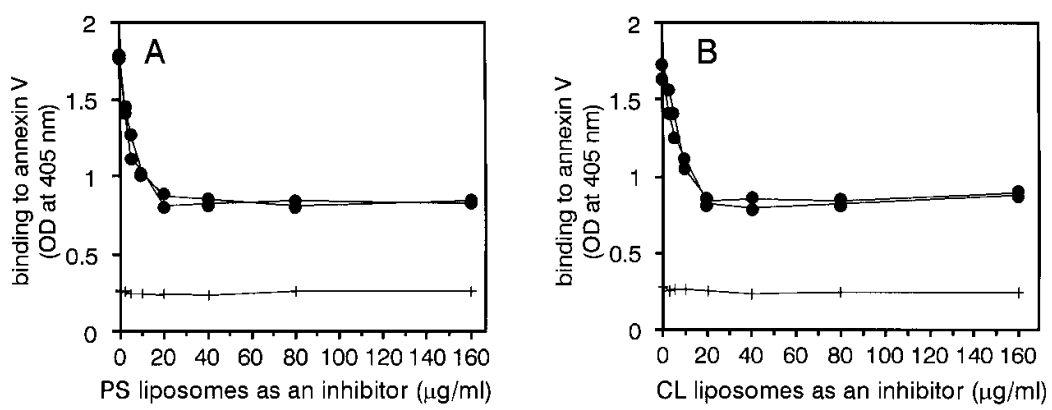

Figure 4. Inhibition of the anti-annexin $\mathrm{V}$ activity of $\mathrm{IgG} /+$ ANX by phospholipids. After the preincubation of $\mathrm{IgG} /+\mathrm{ANX}(20 \mu \mathrm{g} / \mathrm{ml})$ with varying concentrations of liposomes containing PS $(A)$ or $\mathrm{CL}(B)$, the residual antibody binding to annexin $\mathrm{V}$ was measured by ELISA. Two patients were analyzed. Closed circles, IgG/+ANX. +, control IgG.

ligands. The same results were obtained when other kinds of phospholipids or CL-liposome $/ \beta_{2}$ GPI were used as inhibitors. These findings suggested that a subgroup without affinity to phospholipids was included in the IgG/+ANX fraction. On the other hand, annexin $\mathrm{V}$ completely inhibited the binding of $\mathrm{IgG} /+\mathrm{ANX}$ to the coated phospholipids in ELISA (data not shown).

$I g G /+A N X$ induces apoptosis in HUVEC. The plasmas of these patients contained apoptosis-inducing activities in HUVEC (33). Under microscopic observation of HUVEC after a 48-h incubation with patient plasma, some apoptotic cells remained attached to the culture plate, while others were floating in the medium. In either case, the cells shrank and released apoptotic bodies, and were eventually absorbed into the culture medium with or without undergoing a floating process. The time course of apoptosis was monitored by means of the fragmented DNA derived from all cellular components including cellular debris. In parallel, the apoptotic cells which adhered or attached to the plate, termed apoptotic adherent cells (AAC), were counted. The ratio of AAC to all adherent cells (\%AAC) diminished after $24 \mathrm{~h}$ in culture, whereas the fragmented DNA continued to increase during the subsequent 24-h period (Fig. $5 A$ ). The discrepancy was obviously attributable to the fragmented DNA present in the medium, namely that from the detached apoptotic cells, apoptotic bodies, and free DNA released by cell lysis, as the fragmented DNA in the supernatant was increasing. The time course of the apoptosis induced by patient antibodies was similar to that induced by TNF- $\alpha$ (Fig. 5 D), and the fragmented DNA and \%AAC showed a good correlation during the first 24-h culture period. Therefore, we quantified the apoptosis by measuring the fragmented DNA after $24 \mathrm{~h}$ of incubation.

The IgG samples from all 10 patients exhibited apoptosisinducing activity as determined by the DNA fragmentation of HUVEC (Figs. $5 B$ and $6 A$ ). Furthermore, incubation with $\mathrm{IgG} /+$ ANX produced a significant amount $(0.319 \pm 0.010$ [mean \pm SD] OD) of fragmented DNA, while the value, $0.180 \pm 0.009 \mathrm{OD}$, for the $\mathrm{IgG} /-\mathrm{ANX}$ group was similar to those of the IgG controls (Figs. $5 C$ and 6 ). The $\mathrm{IgG} /+\mathrm{ANX}$ samples from three patients generated fragmented DNA in a dose-dependent manner, and their potencies were very similar (Fig. $6 C$ ). In contrast, no substantial fragmentation was observed with $\mathrm{IgG} /-\mathrm{ANX}$ (Fig. $6 \mathrm{C}$ ) or the three IgG controls (data not shown), up to a concentration of 60 or $1,500 \mu \mathrm{g} / \mathrm{ml}$, respectively. Apoptosis was verified by electron microscopic and electrophoretic observations (Fig. 7).

Apoptosis-inducing activity is neutralized by annexin $V$. Subsequently, we attempted to neutralize the apoptosis-inducing activity with annexin $\mathrm{V}$. When patient $\mathrm{IgG}$ or IgG/+ANX was incubated with varying concentrations of annexin $\mathrm{V}$ for 30

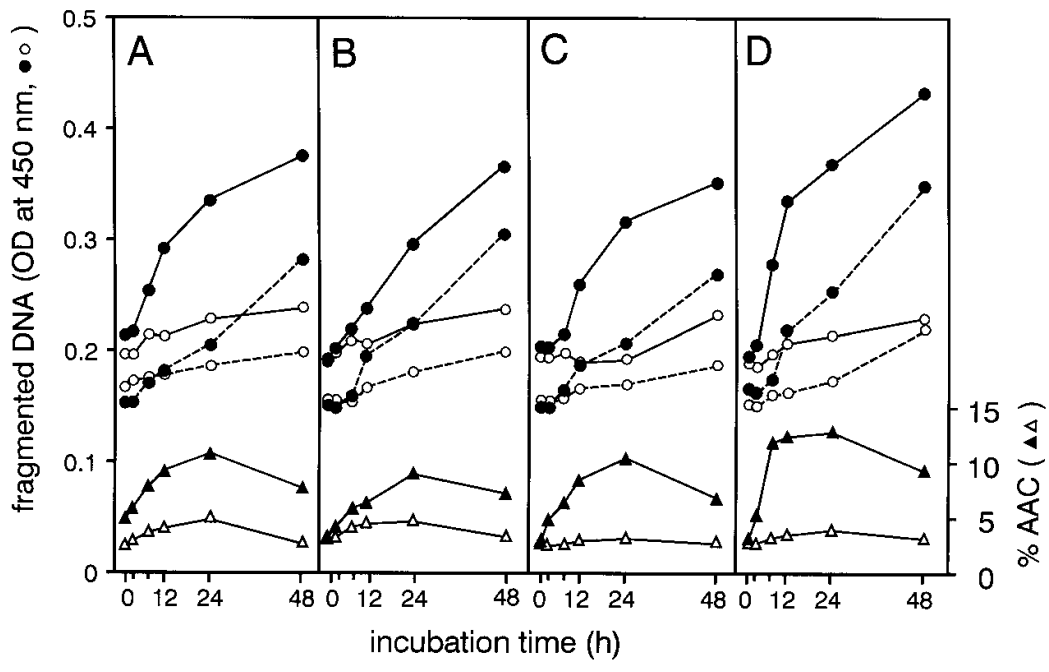

Figure 5. Time course of apoptosis induced by patient $\operatorname{IgG}$. The amounts of fragmented DNA were measured by ELISA, and the means of triplicate measurements are presented. After various culture periods, lysis buffer was added to the wells (solid lines) or to the supernatants after centrifugation (broken lines). For hematoxylin/eosin staining, supernatants in triplicate wells, in which cells had been treated with one of the two test solutions, were removed by aspiration at the indicated time points, and the remaining cells were then stained. The apoptotic cells, among 1,000 adherent cells inspected, were counted and expressed as the percentage of apoptotic adherent cells (\% AAC). (A) Plasma from a patient (closed circles and triangles) and a healthy individual (open circles and triangles). The volume ratio of plasma to culture medium was 1:9. (B) Total IgG isolated from the patient (closed circles and triangles) or the healthy individual (open circles and triangles), at a final concentration of $1.5 \mathrm{mg} / \mathrm{ml}$ in culture medium. (C) Separated

IgGs from the patient. IgG/+ANX (closed circles and triangles) and $\mathrm{IgG} /-\mathrm{ANX}$ (open circles and triangles), at a final concentration of $60 \mu \mathrm{g} / \mathrm{ml}$ in culture medium. (D) TNF- $\alpha$ at a final concentration of $10 \mathrm{ng} / \mathrm{ml}$ (closed circles and triangles) or PBS alone (open circles and triangles). 

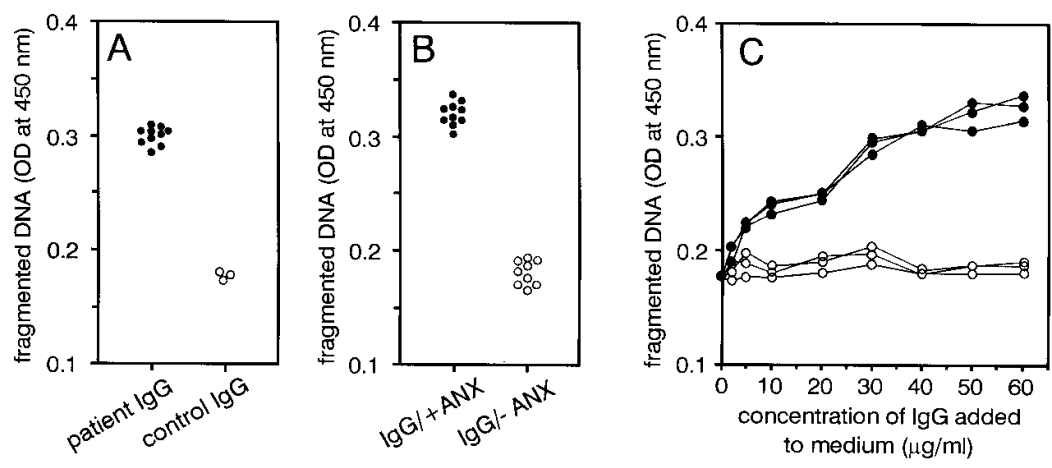

Figure 6. Apoptosis-inducing activities of total and separated IgG antibodies. 5-bromo-2'-deoxyuridinelabeled cells were incubated for $24 \mathrm{~h}$ in the presence of effector solution and DNA fragments were measured. (A) Total IgG at a final concentration of 1.5 $\mathrm{mg} / \mathrm{ml}$. Control IgGs were obtained from two healthy individuals and the pooled plasma. $(B)$ Separated $\mathrm{IgG}$, at a final concentration of $60 \mu \mathrm{g} / \mathrm{ml}$, from patients. $(C)$ Dose-dependent effect of separated IgG antibodies, $\mathrm{IgG} /+\mathrm{ANX}$ (closed circles), or IgG/ -ANX (open circles).

min before addition to HUVEC, the DNA fragmentation was inhibited dose-dependently (Fig. 8, $A$ and $B$ ). Annexin V alone at up to $0.48 \mathrm{mg} / \mathrm{ml}$ neither altered cell viability nor caused DNA fragmentation (Fig. $8 \mathrm{~B}$ ). The concentration of annexin $\mathrm{V}$ required to achieve half-maximal inhibition of the DNA fragmentation generated by $60 \mu \mathrm{g} / \mathrm{ml}$ of $\mathrm{IgG} /+\mathrm{ANX}$ was approximately $80 \mu \mathrm{g} / \mathrm{ml}$ irrespective of the patients studied. On the other hand, $\beta_{2}$ GPI did not affect the apoptotic activity of $\mathrm{IgG} /+\mathrm{ANX}$ (Fig. 9) or of patient $\mathrm{IgG}$ (data not shown).

Apoptosis-inducing activity is not abolished by phospholipid liposomes. The relationship between the phospholipid binding and apoptosis-inducing activities was then studied by adsorbing the former activity with phospholipid liposomes. To achieve this, the IgG solution was incubated with CL- or PSliposomes. After removal of the liposomes by centrifugation followed by extraction, residual activities in the supernatant were measured. As shown in Fig. 10, $A$ and $C$, antiphospholipid antibodies were successfully removed by using a large excess of the corresponding phospholipid liposomes. Unex- pectedly, however, the apoptosis-inducing activities in the supernatant persisted (Fig. 10, $B$ and $D$ ). Similar results were obtained when ESC-liposomes or CL-liposome $/ \beta_{2}$ GPI was used as an adsorber (data not shown).

Annexin $V$ preparation did not contain phospholipids. Finally, it was necessary to exclude the possibility of the neutralizing effect of annexin V (Fig. 8) was due to phospholipids contaminating the annexin $\mathrm{V}$ preparation. To this end, we developed a method for detecting small amounts of phospholipids, taking advantage of the fact that $\mathrm{IgG} /-\mathrm{ANX}$ binds to phospholipids but not to annexin $\mathrm{V}$. The anti-CL activity of $\mathrm{IgG} /-\mathrm{ANX}$ in ELISA was inhibited by CL micelles in a dosedependent manner, and CL at a concentration of, for example, $0.5 \mu \mathrm{g} / \mathrm{ml}$ reduced the binding by $40 \%$ (Fig. $11 A$ ). Therefore, had the annexin $\mathrm{V}$ preparation been contaminated with phospholipids, this would have further decreased the binding of $\mathrm{IgG} /-\mathrm{ANX}$ to phospholipids. However, no such additional reduction was observed, even when up to $500 \mu \mathrm{g} / \mathrm{ml}$ of annexin $\mathrm{V}$ was added to the CL solution (Fig. $11 \mathrm{~B}$ ). A similar result was obtained when ESC was used as a competitor (data not

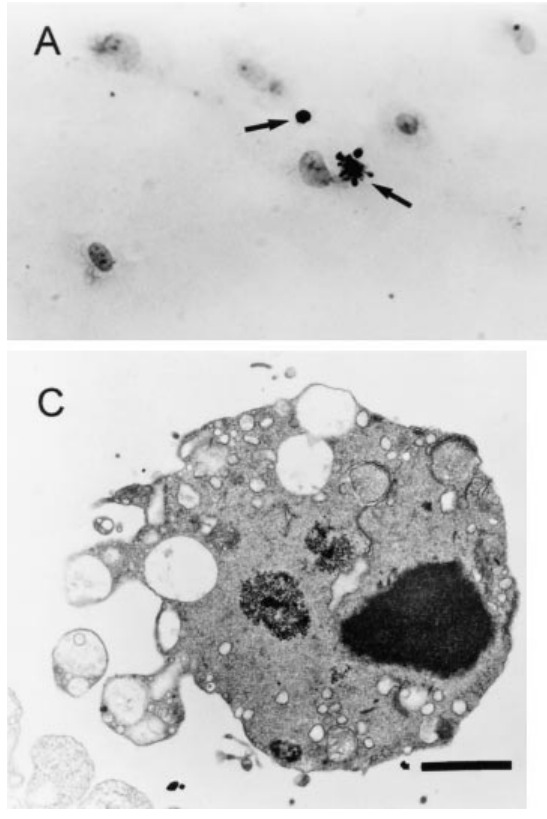

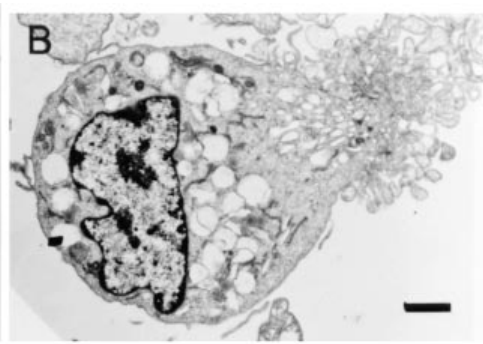

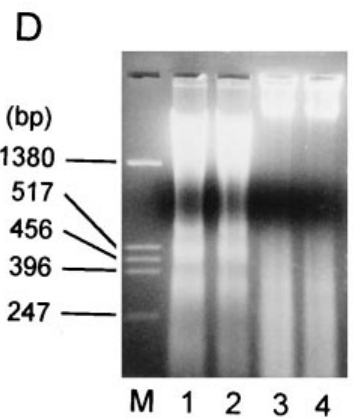

Figure 7. Apoptosis of HUVEC induced by IgG antibodies from patients with LAC. $(A)$ Apoptotic HUVEC stained with hematoxylin/eosin. HUVEC were cultured for $24 \mathrm{~h}$ with a final $60 \mu \mathrm{g} / \mathrm{ml}$ concentration of $\mathrm{IgG} /+\mathrm{ANX}$ from a patient. Arrows show the condensed chromatin in a shrunken apoptotic cell (upper left), and an apoptotic cell containing condensed chromatin in a disintegrated cytoplasmic body (lower right). ( $B$ and $C$ ) Electron micrographs of apoptotic cells. Dilation of the endoplasmic reticulum and disintegration of the cytoplasmic body are observed in $B$. Chromatin condensation, dilation of the endoplasmic reticulum, and cytoplasmic protuberance are remarkable in $C$. Scale bars, $2 \mu \mathrm{m}$. $(D) \mathrm{Gel}$ electrophoresis of fragmented DNA. Cells exposed to $60 \mu \mathrm{g} / \mathrm{ml}$ of IgG/ + ANX (lane 1) or IgG/-ANX (lane 3 ), $1.5 \mathrm{mg} / \mathrm{ml}$ of total $\mathrm{IgG}$ from a patient (lane 2) or a healthy individual (lane 4 ) for $48 \mathrm{~h}$. DNA was extracted from $10^{6}$ floating cells (lanes 1 and 2 ) or $10^{6}$ attached cells (lanes 3 and 4; apoptotic floating cells were rarely observed) and electrophoresed on a $2 \%$ agarose gel. $M$, size markers in base pairs. 

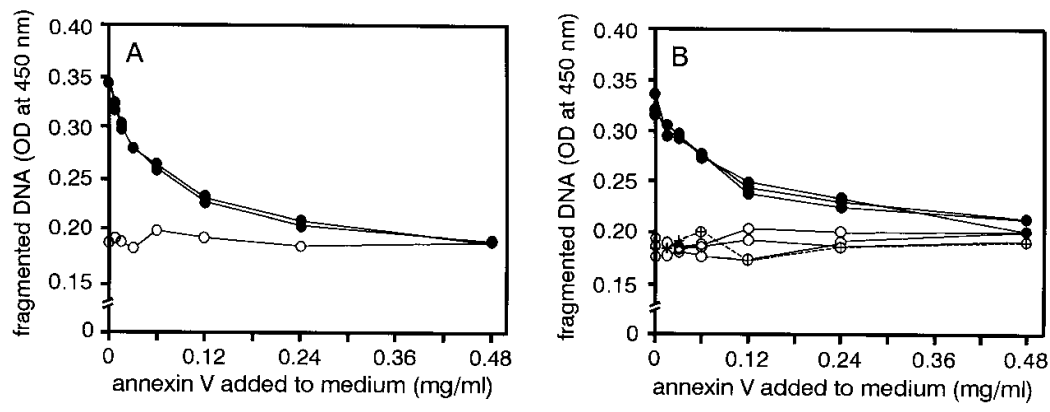

Figure 8. Neutralization of the apoptosis-inducing activity with annexin V. (A) Total IgG from two patients (closed circles) or from control plasma (Standard-Human-Plasma) (open circles), at a final concentration of $1.5 \mathrm{mg} / \mathrm{ml}$, was incubated at $37^{\circ} \mathrm{C}$ for 30 min with varying concentrations of annexin $\mathrm{V}$, and the mixture was then added to HUVEC. Fragmented DNA was measured by ELISA after a 24-h culture. $(B)$ Separated IgGs from three patients, at a final concentration of $60 \mu \mathrm{g} / \mathrm{ml}$, were incubated with annexin $\mathrm{V}$ before being added to HUVEC. IgG/+ ANX (closed circles), IgG/-ANX (open circles). As a control experiment, annexin $\mathrm{V}$ alone was added to the cells (+, with broken lines). shown). Furthermore, preincubation with $0.5 \mu \mathrm{g} / \mathrm{ml}$ of various kinds of phospholipids did not inhibit the apoptosis-inducing activity of IgG/+ANX or patient IgG (data not shown).

\section{Discussion}

LAC exerts its anticoagulation activity in vitro by interfering with phospholipid-dependent coagulation reactions including the conversion of prothrombin to thrombin (52). In recent years, like other antibodies reactive to phospholipids or antiphospholipid antibodies, LAC has also been thought to interact with or bind certain phospholipid-binding proteins and thereby to contribute to a thrombotic diathesis, although the responsible protein remains to be precisely determined, and there may be more than one protein involved $(12,53,54)$.

LAC is associated with thrombosis, not bleeding in vivo. In this study, all plasma samples with obvious LAC activity induced apoptosis in HUVEC. They had the capacity to induce apoptosis in mucosal microvascular endothelial cells and pulmonary artery endothelial cells as well (Nakamura, N., T. Ban, K. Yamaji, Y. Yoneda, and Y. Wada, unpublished observations). From the pathogenic aspect, apoptotic death of endothelial cells provides a promising hypothesis which may explain the paradoxical effect of LAC. Vascular endothelial cells

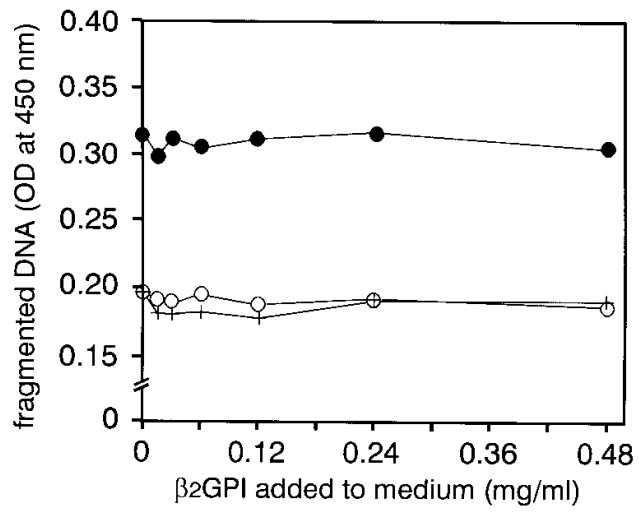

Figure 9. Effect of $\beta_{2}$ GPI on the apoptosis-inducing activity of $\mathrm{IgG} /$ + ANX. IgG/+ ANX (closed circles) or IgG/-ANX (open circles) was preincubated with $\beta_{2}$ GPI, and the mixture was then added to HUVEC culture. As a control experiment, HUVEC were incubated with $\beta_{2}$ GPI alone (+). dominate antithrombotic mechanisms by presenting various molecules such as antithrombin-related heparan sulfate proteoglycan and thrombomodulin on the cell surface or by producing vasodilating mediators. Therefore, apoptotic cell death abolishes these indispensable clot-inhibiting activities. Several studies on the LAC-related thrombosis have focused on the disruption of such biological functions of the endothelium, and diminished cellular activity in culture systems has been noted $(27,28,31)$. Furthermore, the apoptotic cells expose PS on the outer surface of the plasma membrane (55-57), which also activates coagulation cascades $(56,57)$. In the light of our findings, these observations may point to apoptosis of endothelial cells as an underlying cellular event.

In our previous study, all of the monoclonal LACs (51) isolated from a patient with SLE showed binding to the $\mathrm{Ca}^{2+}$ - and phospholipid-binding protein annexin $\mathrm{V}$ and induced apoptosis in HUVEC (33). Therefore, we can speculate that three distinct properties, binding to annexin $\mathrm{V}$, induction of apoptosis, and in vitro anticoagulation, are often present simultaneously in plasma from these patients. In this analysis of 10 patients, both LAC and apoptosis-inducing activities were localized in the $\mathrm{IgG} /+\mathrm{ANX}$ fraction which constituted $2-6 \%$ of $\mathrm{IgG}$ from these patients. This indicates that annexin $\mathrm{V}$ binding may be a property common to the majority of antibodies responsible for endothelial cell apoptosis and the in vitro anticoagulation effect. On the other hand, although the IgG/-ANX fraction also contained phospholipid binding activity, it contained neither LAC nor apoptosis-inducing activities and differed from IgG/ + ANX in its affinity for phospholipid liposomes (Fig. 3).

The apoptosis-inducing as well as antiannexin $\mathrm{V}$ activity persisted in patient IgG after the antiphospholipid activity had been removed by phospholipid liposomes (Fig. 10). This finding suggests the presence of an $\mathrm{IgG}$ group with apoptosisinducing activity but no affinity for phospholipids. Therefore, in such a group, apoptosis-inducing activity would not be associated with LAC activity.

The apoptosis-inducing activity of patient $\mathrm{IgG}$ was not abolished by preincubation with CL-liposome $/ \beta_{2}$ GPI. Furthermore, $\beta_{2}$ GPI did not inhibit the endothelial cell apoptosis induced by IgG/+ANX. These results indicate that $\beta_{2}$ GPI is not involved in endothelial cell apoptosis. This is consistent with our previous findings, in which human monoclonal LACs possessed apoptosis-inducing activity without displaying reactivity to $\mathrm{CL} / \beta_{2} \mathrm{GPI}$ (51).

Annexin $\mathrm{V}$ has a diverse range of in vitro functions and is probably involved in multiple basic cellular functions including 

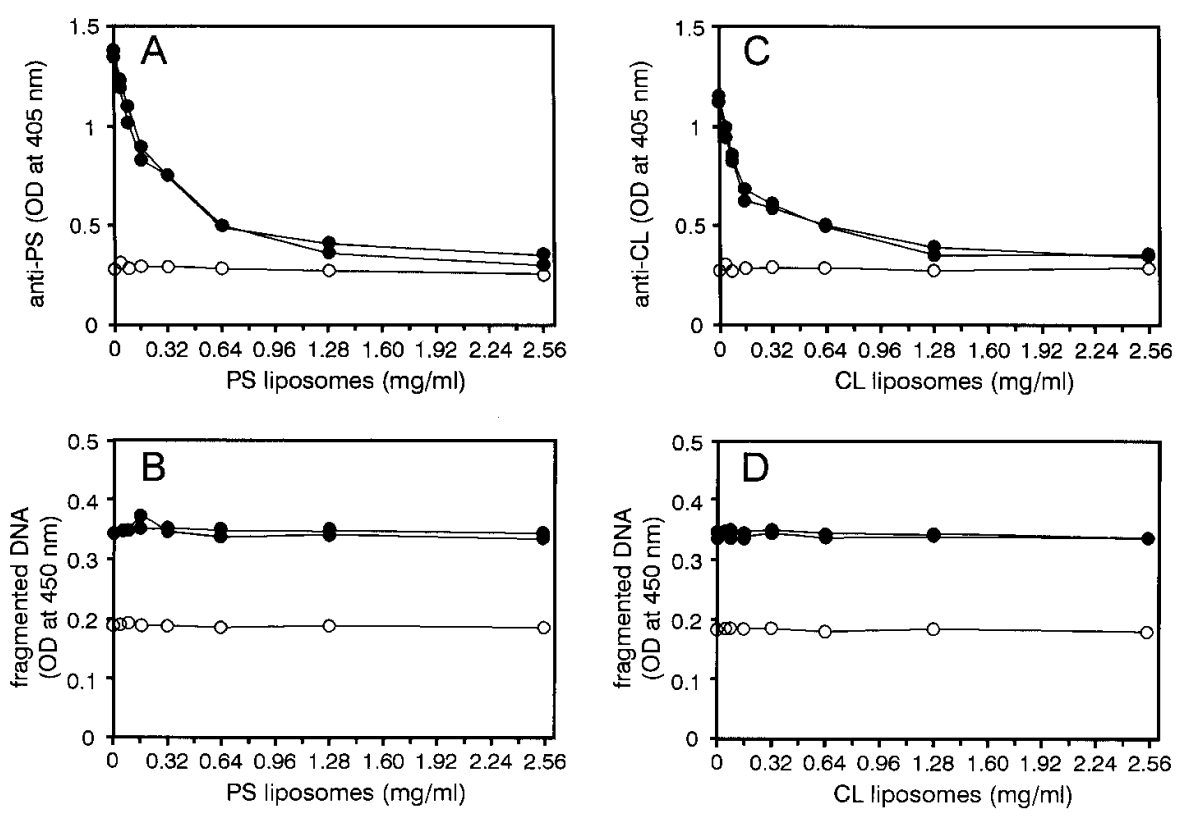

Figure 10. Antiphospholipid and apoptosis-inducing activities of total IgG after preincubation with phospholipid liposomes. Total IgG samples ( $5 \mathrm{mg} / \mathrm{ml} \mathrm{IgG)}$ from patients were incubated with CL-liposomes and the residual CL-binding activities $(A)$ and apoptosis-inducing activities $(B)$ were analyzed by ELISA. Two patients and a healthy individual were examined.

transmembrane $\mathrm{Ca}_{2}{ }^{+}$channel activity (58-60), inhibition of phospholipase $A_{2}(61-63)$ and protein kinase $C(64,65)$, cell matrix interactions (66), regulation of membrane integrity (67), and inhibition of coagulation $(34,35,43)$. Most of these functions are related to its phospholipid binding activity. On the basis of these properties of annexin V, it can be hypothesized that the binding to annexin $\mathrm{V}$ initiates the apoptotic signal via involvement of these functions.

$\mathrm{IgG} /+\mathrm{ANX}$ induced apoptosis at a concentration of $5 \mu \mathrm{g} / \mathrm{ml}$ in culture medium (Fig. $6 \mathrm{C}$ ). Endothelial cells in vivo are presumed to be exposed to this apoptosis-inducing level of effector antibodies in these patients, because the IgG/+ANX fraction constituted more than a small percentage of the total $\mathrm{IgG}$, of which the serum concentration was $10-20 \mathrm{mg} / \mathrm{ml}$. The patient plasma actually induced apoptosis when added at $10 \%$
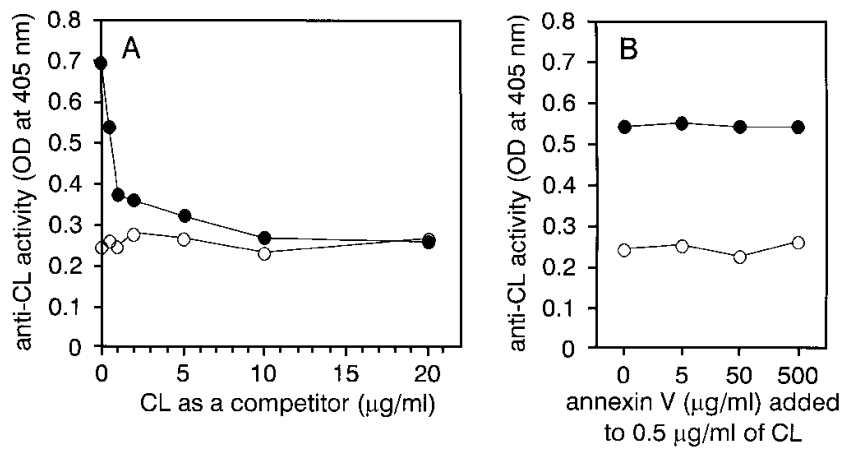

Figure 11. Test for the phospholipid contamination of the annexin $\mathrm{V}$ preparation. (A) Anti-CL activity of $20 \mu \mathrm{g} / \mathrm{ml}$ of IgG/-ANX (closed circles) from a patient were measured by ELISA after incubation with varying concentrations of CL. Control IgG (open circles) was obtained from a healthy individual. (B) Anti-CL activity of $\mathrm{IgG} /-\mathrm{ANX}$ or a control IgG after incubation with varying concentrations of annexin $\mathrm{V}$ added to a mixture of $0.5 \mu \mathrm{g} / \mathrm{ml}$ of $\mathrm{CL}$. (vol/vol) to the culture medium. Nevertheless, these patients do not suffer from thrombotic episodes frequently. This would be explained by the presence of defensive mechanisms in vivo. For example, growth factor is likely to play a role in this system, considering that removal of endothelial cell growth factor from HUVEC culture accelerates LAC-induced apoptosis (33). In addition, annexin V may serve as a defensive molecule by displaying its inherent anticoagulant activity (68-70) or by neutralizing the effector antibody, when released from endothelial cells into the microenvironment.

Multiple pathological mechanisms, rather than a single one, may trigger thrombosis in patients with LAC. For example, Simantov et al. reported that IgG from patients with high titers of anti-CL antibodies activated HUVEC to express cell adhesion molecules (71). They proposed a procoagulant cycle formed by the activated endothelial cells, which involved activated monocytes and inflammatory cytokines. Although the patients in their study were negative for LAC, it is reasonable to speculate that patients with anti-CL antibody and LAC are predisposed to a procoagulant state via such a mechanism. Recently, Rand et al. proposed that the reduced level of annexin $\mathrm{V}$ in the endothelial cells occurs due to exposure to antiphospholipid antibodies and may be an important mechanism of thrombosis (72). Endothelial cell apoptosis may participate in or underlie this mechanism, because apoptotic cell death would reduce the total amount of annexin $\mathrm{V}$, and the anionic phospholipids exposed on the outer leaflet of apoptotic cell membranes may play a major role in the initiation of thrombus formation $(56,57,68,69,73)$.

\section{References}

1. Harris, E.N., A.E. Gharavi, and G.R.V. Hughes. 1985. Anti-phospholipid antibodies. Clin. Rheum. Dis. 11:591-609.

2. Petri, M., M. Rheinshmidt, Q. Whiting-O'Keefe, D. Hellman, and L. Corash. 1987. The frequency of lupus anticoagulant in systemic lupus erythematosus. A study of sixty consecutive patients by activated partial thromboplastin time, Russell viper venom time, and anticardiolipin antibody level. Ann. Intern. Med. 106:524-531. 
3. McNeil, H.P., C.N. Chesterman, and S.A. Krilis. 1991. Immunology and clinical importance of antiphospholipid antibodies. Adv. Immunol. 49:193-280.

4. Harris, E.N., J.K.H. Chan, R.A. Asherson, V.R. Aber, A.E. Gharavi, and G.R.V. Hughes. 1986. Thrombosis, recurrent fetal loss, and thrombocytopenia. Predictive value of the anticardiolipin antibody test. Arch. Intern. Med. 146: 2153-2156.

5. Branch, D.W., J.R. Scott, N.K. Kochenour, and E. Hershgold. 1985. Obstetric complications associated with the lupus anticoagulant. N. Engl. J. Med. 313:1322-1326.

6. Feinstein, D.I. 1985. Lupus anticoagulant, thrombosis, and fetal loss. $N$. Engl. J. Med. 313:1348-1350.

7. Sammaritano, L.R., A.E. Gharavi, and M.D. Lockshin. 1990. Antiphospholipid antibody syndrome: immunologic and clinical aspects. Semin. Arthritis Rheum. 20:81-96.

8. Bevers, E.M., M. Galli, T. Barbui, P. Comfurius, and R.F.A. Zwaal. 1991. Lupus anticoagulant IgG's (LA) are not directed to phospholipids only, but to a complex of lipid-bound human prothrombin. Thromb. Haemost. 66:629-632.

9. Triplett, D.A. 1992. Antiphospholipid antibodies: proposed mechanisms of action. Am. J. Reprod. Immunol. 28:211-215.

10. Vermylen, J., and J. Arnout. 1992. Is the antiphospholipid syndrome caused by antibodies directed against physiologically relevant phospholipidprotein complexes? J. Lab. Clin. Med. 120:10-12.

11. Santoro, S.A. 1994. Antiphospholipid antibodies and thrombotic predisposition: underlying pathogenetic mechanisms. Blood. 83:2389-2391.

12. Roubey, R.A.S. 1994. Autoantibodies to phospholipid-binding plasma proteins: a new view of lupus anticoagulants and other "antiphospholipid" autoantibodies. Blood. 84:2854-2867.

13. Rao, L.V.M., A.D. Hoang, and S.I. Rapaport. 1995. Differences in the interactions of lupus anticoagulant $\mathrm{IgG}$ with human prothrombin and bovine prothrombin. Thromb. Haemost. 73:668-674.

14. Triplett, D.A. 1995. Antiphospholipid-protein antibodies: laboratory detection and clinical relevance. Thromb. Res. 78:1-31.

15. Nilsson, T.K., and E. Löfvenberg. 1989. Decreased fibrinolytic capacity and increased von Willebrand factor levels as indicators of endothelial cell dysfunction in patients with lupus anticoagulant. Clin. Rheumatol. 8:58-63.

16. Tsakiris, D.A., G.A. Marbet, P.E. Makris, L. Settas, and F. Duckert. 1989. Impaired fibrinolysis as an essential contribution to thrombosis in patients with lupus anticoagulant. Thromb. Haemost. 61:175-177.

17. Sanfelippo, M.J., and C.J. Drayna. 1982. Prekallikrein inhibition associated with the lupus anticoagulant. Am. J. Clin. Pathol. 77:275-279.

18. Carreras, L.O., and J.G. Vermylen. 1982. "Lupus" anticoagulant and thrombosis-possible role of inhibition of prostacyclin formation. Thromb. Haemost. 48:38-40.

19. Schorer, A.E., N.W.R. Wickham, and K.V. Watson. 1989. Lupus anticoagulant induces a selective defect in thrombin-mediated endothelial prostacyclin release and platelet aggregation. Br. J. Haematol. 71:399-407.

20. Martinuzzo, M.E., J. Maclouf, L.O. Carreras, and S. Lévy-Toledano. 1993. Antiphospholipid antibodies enhance thrombin-induced platelet activation and thromboxane formation. Thromb. Haemost. 70:667-671.

21. Freyssinet, J.-M., M.-L. Wiesel, J. Gauchy, B. Boneu, and J.-P. Cazenave. 1986. An IgM lupus anticoagulant that neutralizes the enhancing effect of phospholipid on purified endothelial thrombomodulin activity-a mechanism for thrombosis. Thromb. Haemost. 55:309-313.

22. Tsakiris, D.A., L. Settas, P.E. Makris, and G.A. Marbet. 1990. Lupus anticoagulant-antiphospholipid antibodies and thrombophilia. Relation to protein C-protein S-thrombomodulin. J. Rheumatol. 17:785-789.

23. Amer, L., W. Kisiel, R.P. Searles, and R.C. Williams, Jr. 1990. Impairment of the protein $\mathrm{C}$ anticoagulant pathway in a patient with systemic lupus erythematosus, anticardiolipin antibodies, and thrombosis. Thromb. Res. 57: 247-258

24. Malia, R.G., S. Kitchen, M. Greaves, and F.E. Preston. 1990. Inhibition of activated protein $\mathrm{C}$ and its cofactor protein $\mathrm{S}$ by antiphospholipid antibodies. Br. J. Haematol. 76:101-107.

25. Smirnov, M.D., D.A. Triplett, P.C. Comp, N.L. Esmon, and C.T. Esmon. 1995. On the role of phosphatidylethanolamine in the inhibition of activated protein C activity by antiphospholipid antibodies. J. Clin. Invest. 95:309-316.

26. Bokarewa, M.I., K. Bremme, G. Falk, M. Sten-Linder, N. Egberg, and M. Blombäck. 1995. Studies on phospholipid antibodies, APC-resistance, and associated mutation in the coagulation factor V gene. Thromb. Res. 78:193-200.

27. Cariou, R., G. Tobelem, S. Belluci, C. Belluci, J. Soria, C. Soria, J. Maclouf, and J. Caen. 1988. Effect of lupus anticoagulant on antithrombogenic properties of endothelial cells. Inhibition of thrombomodulin-dependent protein C activation. Thromb. Haemost. 60:54-58.

28. Cervera, R., M.A. Khamashta, J. Font, G. Ramirez, D. D'Cruz, J. Montalbán, A. López-Soto, R.A. Asherson, M. Ingelmo, and R.V. Hughes. 1991. Antiendothelial cell antibodies in patients with the antiphospholipid syndrome. Autoimmunity. 11:1-6.

29. Gleicher, N., L. Harlow, and M. Zilberstein. 1992. Regulatory effect of antiphospholipid antibodies on signal transduction: a possible model for autoantibody-induced reproductive failure. Am. J. Obstet. Gynecol. 167:637-642.

30. Carreras, L.O., and J. Maclouf. 1993. The lupus anticoagulant and eicosanoids. Prostaglandins Leukot. Essent. Fatty Acids. 49:483-488.
31. Branch, D.W., and G.M. Rodgers. 1993. Induction of endothelial cell tissue factor activity by sera from patients with antiphospholipid syndrome: a possible mechanism of thrombosis. Am. J. Obstet. Gynecol. 168:206-210.

32. Lockshin, M.D. 1995. Answers to the antiphospholipid-antibody syndrome? N. Engl. J. Med. 332:1025-1027.

33. Nakamura, N., Y. Shidara, N. Kawaguchi, C. Azuma, N. Mitsuda, S. Onishi, K. Yamaji, and Y. Wada. 1994. Lupus anticoagulant autoantibody induces apoptosis in umbilical vein endothelial cells: involvement of annexin V. Biochem. Biophys. Res. Commun. 205:1488-1493.

34. Reutelingsperger, C.P.M., G. Hornstra, and H. Hemker. 1985. Isolation and partial purification of a novel anticoagulant from arteries of human umbilical cord. Eur. J. Biochem. 151:625-629.

35. Funakoshi, T., R.L. Heimark, L.E. Hendrickson, B.A. McMullen, and K. Fujikawa. 1987. Human placental anticoagulant protein: isolation and characterization. Biochemistry. 26:5572-5578.

36. Iwasaki, A., M. Suda, H. Nakao, T. Nagoya, Y. Saino, K. Arai, T. Mizoguchi, F. Sato, H. Yoshizaki, M. Hirata, T. Miyata, et al. 1987. Structure and expression of cDNA for an inhibitor of blood coagulation isolated from human placenta: a new lipocortin-like protein. J. Biochem. (Tokyo). 102:1261-1273.

37. Tait, J.F., D. Gibson, and K. Fujikawa. 1989. Phospholipid binding properties of human placental anticoagulant protein-I, a member of the lipocortin family. J. Biol. Chem. 264:7944-7949.

38. Creutz, C.E. 1992. The annexins and exocytosis. Science. 258:924-931.

39. Raynal, P., and H.B. Pollard. 1994. Annexins: the problem of assessing the biological role for a gene family of multifunctional calcium- and phospholipid-binding proteins. Biochim. Biophys. Acta. 1197:63-93.

40. van Heerde, W.L., P.G. de Groot, and C.P.M. Reutelingsperger. 1995. The complexity of the phospholipid binding protein annexin V. Thromb. Haemost. 73:172-179.

41. Nakamura, N., C. Kuragaki, Y. Shidara, K. Yamaji, and Y. Wada. 1995. Antibody to annexin $\mathrm{V}$ has anti-phospholipid and lupus anticoagulant properties. Am. J. Hematol. 49:347-348.

42. Tan, E.M., A.S. Cohen, J.F. Fries, A.T. Masi, D.J. McShane, N.F. Rothfield, J.C. Schaller, N. Talal, and P.J. Winchester. 1982. The 1982 revised criteria for the classification of systemic lupus erythematosus. Arthritis and Rheum. 25:1271-1277.

43. Maki, M., M. Murata, and Y. Shidara. 1984. Inhibitors of platelet aggregation and blood coagulation isolated from the human placenta. Eur. J. Obstet. Gynecol. Reprod. Biol. 17:149-154.

44. Wurm, H. 1984. Beta 2-glycoprotein-I (apolipoprotein H) interactions with phospholipid vesicles. Int J. Biochem. 16:511-515.

45. Ito, M., M. Watanabe, T. Ihara, H. Kamiya, and M. Sakurai. 1995. Fas antigen and bcl-2 expression on lymphocytes cultured with cytomegalovirus and varicella-zoster virus antigen. Cell. Immunol. 160:173-177.

46. Matsuura, E., Y. Igarashi., T. Yasuda, D.A. Triplett, and T. Koike. 1994. Anticardiolipin antibodies recognize $\beta_{2}$-GPI structure altered by interacting with an oxygen modified solid phase surface. J. Exp. Med. 179:457-462.

47. Tsutsumi, A., E. Matsuura, K. Ichikawa, A. Fujisaku, M. Mukai, S. Kobayashi, and T. Koike. 1996. Antibodies to $\beta_{2}$-glycoprotein-I and clinical manifestations in patients with systemic lupus erythematosus. Arthritis Rheum. 39:1466-1474.

48. Roubey, R.A.S., R.A. Eisenberg, M.F. Harper, and J.B. Winfield. 1995 "Anticardiolipin" autoantibodies recognize $\beta_{2}$-glycoprotein-I in the absence of phospholipid. Importance of Ag density and bivalent binding. J. Immunol. 154: 954-960.

49. Forastiero, R.R., M.E. Martinuzzo, L.C. Kordich, and L.O. Carreras. 1996. Reactivity to $\beta_{2}$ glycoprotein-I clearly differentiates anticardiolipin antibodies from antiphospholipid syndrome and syphilis. Thromb. Haemost. 75: 717-720.

50. Roubey, R.A.S., M.A. Maldonado, and S.N. Byrd. 1996. Comparison of an enzyme-linked immunosorbent assay for antibodies to $\beta_{2}$-glycoprotein-I and a conventional anticardiolipin immunoassay. Arthritis Rheum. 39:1606-1607.

51. Nakamura, N., C. Azuma, T. Akamizu, H. Sugawa, F. Matsuda, N. Mitsuda, T. Honjo, T. Mori, and K. Yamaji. 1994. Heterogeneity and diversity of IgM and IgG lupus anticoagulants in an individual with systemic lupus erythematosus. Biochem. Biophys. Res. Commun. 203:1789-1794.

52. Pierangeli, S.S., J. Dean, G.H. Goldsmith, D.W. Branch, A. Gharavi, and E.N. Harris. 1996. Studies on the interaction of placental anticoagulant protein I, $\beta_{2}$ glycoprotein 1 , and antiphospholipid antibodies in the prothrombinase reaction and in the solid phase anticardiolipin assays. J. Lab. Clin. Med. 128: 194-201.

53. Roubey, R.A.S. 1996. Immunology of the antiphospholipid antibody syndrome. Arthritis. Rheum. 39:1444-1454.

54. Galli, M. 1996. Non beta 2-glycoprotein-I cofactors for antiphospholipid antibodies. Lupus. 5:388-392.

55. Bennett, M.R., D.F. Gibson, S.M. Schwartz, and J.F. Tait. 1995. Binding and phagocytosis of apoptotic vascular smooth muscle cells is mediated in part by exposure of phoshatidylserine. Circ. Res. 77:1136-1142.

56. Bombeli, T., A. Karsan, J.F. Tait, and J.M. Harlan. 1997. Apoptotic vascular endothelial cells become procoagulant. Blood. 89:2429-2442.

57. Casciola-Rosen, L., A. Rosen, M. Petri, and M. Schlissel. 1996. Surface blebs on apoptotic cells are sites of enhanced procoagulant activity: implica- 
tions for coagulation events and antigenic spread in systemic lupus erythematosus. Proc. Natl. Acad. Sci. USA. 93:1624-1629.

58. Rojas, E., H.B. Pollard, H.T. Haigler, C. Parra, and A.L. Burns. 1990. Calcium-activated endonexin II forms calcium channels across acidic phospholipid bilayer membranes. J. Biol. Chem. 265:21207-21215.

59. Matsuda, R., N. Kaneko, and Y. Horikawa. 1997. Presence and comparison of $\mathrm{Ca}_{2}{ }^{+}$transport activity of annexins I, II, V, and VI in large unilamellar vesicles. Biochem. Biophys. Res. Commun. 237:499-503.

60. Arispe, N., E. Rojas, B.R. Genge, L.N. Wu, and R.E. Wuthier. 1996. Similarity in calcium channel activity of annexin $\mathrm{V}$ and matrix vesicles in planar lipid bilayers. Biophys. J. 71:1764-1775.

61. Ahn, N.G., D.C. Teller, M.J. Bienkowski, B.A. McMullen, E.W. Lipkin, and C. de Haën. 1988. Sedimentation equilibrium analysis of five lipocortinrelated phospholipase A2 inhibitors from human placenta. J. Biol. Chem. 263: 18657-18663.

62. Mira, J.P., T. Dubois, J.P. Oudinet, S. Lukowski, F. Russo-Marie, and B. Geny. 1997. Inhibition of cytosolic phospholipase $A_{2}$ by annexin V in differentiated permeabilized HL-60 cells. Evidence of crucial importance of domain I type II $\mathrm{Ca}_{2}{ }^{+}$-binding site in the mechanism of inhibition. J. Biol. Chem. 272: 10474-10482.

63. Speijer, H., S.W. Jans, C.P. Reutelingsperger, C.E. Hack, G.J. van der Vusse, and W.T. Hermens. 1997. Partial coverage of phospholipid model membranes with annexin $\mathrm{V}$ may completely inhibit their degradation by phospholipase $\mathrm{A}_{2}$. FEBS Lett. 402:193-197.

64. Schlaepfer, D.D., J. Jones, and H.T. Haigler. 1992. Inhibition of protein kinase C by annexin V. Biochemistry. 31:1886-1891.

65. Routhhut, B., T. Dubois, D. Feliers, F. Russo-Marie, and J-P. Oudinet. 1995. Inhibitory effect of annexin $\mathrm{V}$ on protein kinase $\mathrm{C}$ activity in mesangial cell lysates. Eur. J. Biochem. 232:865-872.

66. King, K.B., S. Chubinskaya, D.L. Reid, L.H. Madsen, and J. Mollenhauer. 1997. Absence of cell-surface annexin V is accompanied by defective collagen matrix binding in the Swarm rat chondrosarcoma. J. Cell. Biochem. 65: $131-144$.

67. Goossens, E.L.J., C.P.M. Reutelingsperger, F.H.M. Jongsma, R. Kraayenhof, and W.T. Hermens. 1995. Annexin V perturbs or stabilises phospholipid membranes in a calcium-dependent manner. FEBS Lett. 359:155-158.

68. van Heerde, W.L., K.S. Sakariassen, H.C. Hemker, J.J. Sixma, C.P.M Reutelingsperger, and P.G. de Groot. 1994. Annexin V inhibits the procoagulant activity of matrices of TNF-stimulated endothelium under blood flow conditions. Arterioscler. Thromb. 14:824-830.

69. van Heerde, W.L., S. Poort, C. van't Veer, C.P.M. Reutelingsperger, and P.G. de Groot. 1994. Binding of recombinant annexin V to endothelial cells: effect of annexin $\mathrm{V}$ binding on endothelial-cell-mediated thrombin formation. Biochem. J. 302:305-312

70. Thiagarajan, P., and C.R. Benedict. 1997. Inhibition of arterial thrombosis by recombinant annexin $\mathrm{V}$ in a rabbit carotid artery injury model. Circulation. 96:2339-2347.

71. Simantov, R., J.M. LaSala, S.K. Lo, A.E. Gharavi, L.R. Sammaritano, J.E. Salmon, and R.L. Silverstein. 1995. Activation of cultured vascular endothelial cells by antiphospholipid antibodies. J. Clin. Invest. 96:2211-2219.

72. Rand, J.H., X.X. Wu, H.A.M. Andree, C.J. Lockwood, S. Guller, J. Scher, and P.C. Harpel. 1997. Pregnancy loss in the antiphospholipid-antibody syndrome-a possible thrombogenic mechanism. N. Engl. J. Med. 337:154-160.

73. Reutelingsperger, C.P.M., and W.L. van Heerde. 1997. Annexin V, the regulator of phosphatidylserine-catalyzed inflammation and coagulation during apoptosis. Cell. Mol. Life Sci. 53:527-532. 